\title{
Megjegyzések Sükösd Miklós tanulmányához
}

\section{Szerzői információ:}

O Dr. Pásztor János

Református lelkész, egyetemi tanár, a theológiai tududományok doktora. Segédlelkészként, majd lelki pásztorként is dolgozott 1952 és 1970 között. Egyetemi tanár a Debreceni Református Theologiai Akadémián (1976-87), majd 1993-tól a Budapesti Református Theologiai Akadémián és a Károli Gáspár Református Egyetem Hittudományi Karán oktat. 1990-tôl számos külföldi egyetemen vendégtanár: a bécsi Egyetem Hittudományi Karán 199091; Princeton Theological Seminary Wearfield Lecturer 1992; Dubuque Egyetem, Iowa, USA Hittudományi Kara 1993-94; Texas Christian University Brite Divinity School 1997 nyári szemeszter; Columbia Theologiai Fakultás Decatur Georgia 1997-98; Evangelical Theological Faculty Eszék/Osijek Horvátország 1998-99.I.félév, 2002-03. 1. félév; Columbia Theologiai Fakultás Decatur, Georgia, USA 1987-88; Campbrell Scholar Columbia Seminary Decatur Georgia

Így hivatkozzon erre a cikkre:

Pásztor János. „Megjegyzések Sükösd Miklós tanulmányához”.

Információs Társadalom IV, 3-4. szám (2004): 21-25.

$\mathbf{L}$ https://dx.doi.org/10.22503/inftars.IV.2004.3-4.3

A folyóiratban közölt müvek

a Creative Commons Nevezd meg! - Ne add el! - Így add tovább! 4.0

Nemzetközi Licenc feltételeinek megfelelöen használhatók. 
Pás z t o r Ján o s

\section{Megjegyzések Sükösd Miklós tanulmá-}

\section{nyához}

Hálás vagyok, hogy Sükösd Miklós írását elolvashattam. Remek analízist ad a mai társadalomnak a médiához való viszonyáról, valamint a valóságos és az ember által kreált mesterséges világról, és ezek egymásra hatásáról. Hangsúlyos írásában, hogy felelőtlenség, majdnem hogy öngyilkosság bezárkózni a média világba, és elfeledkezni a környezetről, mert annak pusztulása - a folyó bưze - betör a tv-szobánkba is. Nem lehet elmenekülni. A dolgokkal szembe kell nézni.

Nagyon jól mutat rá a szerzô a médiavilág és az ökológai válság összefüggéseire. Kitûnő példája ez az írás annak is, hogy az életben minden összefügg: a mai valóság, a történelem, a hely, és a magunk által teremtett világ. Ezen a ponton Ludwig Feuerbach gondolata jut eszembe, aki szerint nem Isten teremtette az embert, hanem az ember teremtette meg önmagában az istenképet, azt projiciálja, kivetíti magából, és imádja azt. Feuerbach ezt a látást Izrael babiloni fogsága nagy prófétájától, Második Ézsaiástól vette. Ó leírja az ács munkáját. Károli fordítja „ács”-nak az eredeti szövegben itt használt Biblia a „famíves” szót alkalmazza. ${ }^{1}$ Fordíthatjuk a héber szót faszobrásznak is, aki fából sok mindent farag. Válogat, és ízlése szerint formálja a fát. Ez szép és nagyszerű dolog. Mikor mindennel készen van, a faforgácssal megmelegíti ételét.

Ezután elromlik a dolog: „Maradékából istent készít, bálványát; leborulva imádja azt és könyörög hozzá... Szabadíts meg, mert te vagy istenem.” (Ézs. 44,17) Gyönyörû́en leírja a bálvány keletkezését. Az ember, akinek istenadta tehetsége van az alkotásra, és alkot valóban nagyszerû dolgokat, utána bálványimádásával mindent elront. Feuerbach Ézsaiástól tanult, amikor az istenteremtésről beszélt. Azt azonban nem tanulta meg, ami Ézsaiásnál a lényeg: „Így szól az Úr, Izrael királya és megváltója [...] Én vagyok az elsố és az utolsó, és rajtam kívül nincsen Isten.” (Ézs. 44,6) Van tehát egy élő Isten, aki magának népet választott az ellene lázadásban bálványokat alkotó és imádó népek között. Tette ezt azért, hogy ez a nép az egész emberiség számára felajánlott szabadításának munkása legyen.

Az is figyelemreméltó, hogy Ézsaiás e sorokat a babiloni fogságban írta Izrael történelme egyik legnagyobb krízise idején. Amikor úgy tûnt: Izrael Istene, Jahveh megbukott. Legyőzték a babiloni istenek, kiknek templomait romjaikban is csodálja a világ. Ézsaiás elismeri a szobrászok, és általában az anyaggal dolgozó mûvészek és kézművesek munkáját. Tudja azonban, hogy amikor alkotó feladatukon - amivel a Teremtô Isten munkatársai - túllépnek, akkor túllépnek határaikon és hiábavalóságot csinálnak. Nem szédítették ôt az építészet és szobrászat csodái, amelyek Babilonban a bálványimádás szolgálatában álltak.

${ }^{1}$ Raj Tamás (szerk.) BIBLIA (Budapest: Makkabi Kiadó, 1994). II. kötet. 108 
Bizonyos mértékű anakronizmussal azt mondhatnánk, hogy Babilonban, az ókor nagy birodalmában - mint általában az ókori nagy birodalmakban - a korai globalizáció előképeit láthatjuk. Azért jöhettek ezek létre, mert a kor technikáját jól megszervezve képesek voltak hatalmas birodalmakat létrehozni. Ebben a hatalmas birodalomban van egy csomó deportált, rabszolgaszerű nép, köztük Ézsaiás népe, mely tudja, és a fogság krízisei között újra tanulta, hogy nem a templom és bálványai megépítésével lesz a Zigurratokban elérhető az Isten. Nem, ő ott van jelen, ahol az Ô Szava szól. Ez az Ézsaiáson és Ezékielen keresztül megszólaló Szó, az Isteni Ige fordította meg a rabnép sorsát. Ez az Ige lett testté és minden nép számára elérhetôvé Krisztusban.

Itt vagyunk a 21. század globalizálódó világában. Mára a már Babilonban is megcsodált technika hihetetlen bonyolultságban tovább fejlődött, és mind építésre, mind rombolásra rendkívül alkalmas lett. A haditechnika félelmes fejlődését ismerjük. Azt is tudjuk, hogy a korlátlan és felelôtlen iparfejlesztés elvezetett az ökológai válsághoz. Mindennek része az elektronikus információterjedés forradalma. Tudomásom szerint az e-mailt először az első öbölháború idején használta tömegesen a Pentagon, az Irakban harcoló csapatok közötti összeköttetés gyorsítására.

Az életben és a világban minden összefügg. Minél tökéletesebb a technika, annál erôteljesebb az interakció, és annál több veszedelmet rejt magában.

Számomra Sükösd Miklós tanulmánya errôl szól, amikor a totális médialitásban kimutatja e bonyolult, komplex szituáció összefüggéseit az ökológiai válsággal, az ökocídiummal.

Azok közé tartozom, akik számára Istennek a Babilonban is megszólaló igéje, aki az „idôk teljességében” a názáreti Jézusban lett tökéletesen testté, az élet alapja, tartalma és erőforrása. Ebben az alapvetô meghatározottságban vagyok itt a globalizáció közepette és írom ezeket a sorokat a computeren, és fogom ezt az írást továbbküldeni e-mailen.

Ebben a kettôsségben Isten igéjétốl meghatározva élek a globalizált világban, és próbálom nemcsak a magam, hanem embertársaim számára is keresni az emberséges utat. Ebben a szellemben szeretnék az írás egyes ide vonatkozó részleteihez hozzászólni.

Ebben a tanulmányban a két szféra dinamikus viszonyának nagyszerủ szemléltetését kapjuk. Valóban, a média világa időben és tartalomban is egyre több időt és energiát vesz el tőlünk, és formálja, alakítja gondolkozásunkat, ahogy mi alakítottuk és létrehoztuk a médiát mai formájában. Erre is érvényes az ézsaiási faszobrász tevékenységének a leírása: egyfelôl csodálatos az egész, másfelôl bálvánnyá lett, amit posztmodern módon nem a Zigurratokban imádunk, hanem talán a képernyő elốtt.

Sükösd Miklós ezt írja: „Elvonjuk, kivonjuk magunkat a valóságos téridőből a médiavalóságba. Minél több idốt töltünk ott, annál kevesebbet vagyunk itt. A médiatérbe helyezett tudat eltávolodik az elsődleges környezettôl, ezen belül különösen a természeti környezettől."

Ez a mondat és az egész tanulmány megrendítôen illusztrálja a „nem létező”nek tartott tényezốk valóságát. A egész cyberspace business az ember által teremett alkotás, amely lehet az eredményes munkavégzés eszköze. Lehet azonban a rombolás eszköze is a háborúkban, a környezet elpusztításában, és a saját belsô világunk pszichológiai értelemben vett lerombolásában. A technika ilyen használata mögött tipikusan bálványimádó magatartás van: én alkottam valamit, ami fölém növekedett, mint Goethe Zauberlehrning-je fölé a kiáradó víz. Az ökológai válsággal kapcsolatos megdöb- 
bentô felelôtlenség a világ hatalmasai részérôl is illusztrálja, hogy az ember alkotta bálvány quasi önállóságra kel, és Frankenstein fiaként rombol és pusztít.

Sükösd beszél a démoni erőkrôl is. Azok valóságát döbbenetesen illusztrálja. Érdemes a démonokkal kapcsolatos bibliai tanítást is felidézni. A bibliakutatókat két határozottan elkülönülő csoportra lehet osztani.

A) Az egyik az, amelyik a Szentírás szövegét tisztelve, arra alapozva - Isten Lelke vezetését kérve imádságban - odafigyel. Így megérti magából a Szentírásból, hogy itt nem valami, a mennyből angyali helikopteren az ember számára ledobott mágikus írásról van szó, hanem a történelmet alkotó és Fiában a történelembe belépő Istennek embereken át megszólaló Szaváról és annak elfogadásáról. Ezért a Bibliának kettôs természete van: Isten szava és ember szava. ${ }^{2}$ A Biblia Isten szava, úgy, hogy ember szava is. Mivel pedig az ember recepciója és arra adott válasza hozzátartozik az isteni Szóhoz, nem lehetséges a Biblia csalatkozatlanságáról beszélni. Szövegei magán hordozzák a kor kultúráját, azon belüli ismeretvilágát. Ez nemcsak megengedetté, hanem szükségessé is teszi a bibliakutatást mind a történelmi háttér (kontextus), mind pedig az irodalomtörténet szempontjából.

B) A másik csoport a Bibliát ahistorikusan szemléli, és azt Isten tévedhetetlen szavának, történeti és irodalmi kutatását a szent szöveg elleni támadásnak tekinti. Itt a probléma az, hogy nem számol a bibliaolvasó és a bibliakutató recepciókészségének gyarlóságaival. Lényegében ezt tekinti tévedhetetlennek. Ezt a csoportot szokás fundamentalistának is nevezni.

Ez a kétféle megközelítés megmutatkozik a démonokról szóló tanításban is. A bibliakutatók között - teljesen agnosztikus vagy ateista kutatókat nem számítva kétféle felfogás létezik.

A) A személyes Sátánban való hit, ami a fundamentalistáknál szinte üdvösségkérdés. Elvileg vallják ugyan a Sátánnak Isten alá való vettetését, e jelenvaló világot a Biblia határozott tanítása ellenére a Sátán uralma alatt látják (Zsolt. 97,1; Jel. 11,15). A Sátánról való beszédük néha már az ôsi perzsa (zoroaszteri) abszolút dualizmust közelíti meg.

B) A másik látásmód is teljességgel komolyan veszi a démoni erôk jelenlétét a történelemben, melyek erôsebbek az embernél, noha azok létrejöttében az embernek is szerepe van. A démonokról való beszéd különösen az ún. apokaliptikus irodalomban jelentôs.

Az apokaliptikus könyvekben - elsốsorban Dániel Könyve esetében - a Jelenések Könyvében is a központi téma: a történelem és az örökkévalóság találkozása. Ez a látás már Izraelt is világtörténelmi perspektívába helyezi. Az apokaliptika nyelve minderre rendkívül alkalmas. Itt ugyanis pontosan errôl van szó: a mindennapi tapasztalatok világába belép a láthatatlan, megfoghatatlan Isten, aki Krisztusban láthatóvá és megfoghatóvá lett (1 Jn. 1,1), hogy új élettartalmat adjon, és erőt közöljön annak megvalósítására. Itt a megfoghatatlan hétköznapi realitássá lett, mert az isteni beavatkozás Krisztusban már megtörtént. Ezt az irodalmat a szimbolikus nyelv és a szimbolikus számrend használata jellemzi. Ebben a megszemélyesítésnek, a perszonifiká-

\footnotetext{
${ }^{2}$ Bolyki János, “ A Szentírás kettős természetérôl. " in: Fabinyi Tibor (szerk.) Kinyilatkoætatás: két megközelités, (Budapest: Hermeneutikai Kutatóközpont, 1997)
} 
ciónak nagy jelentôsége van. Ezért sokak szerint helyesebb démoni erôkrốl beszélni, melyek valóságát nem lehet figyelmen kívül hagyni. Azok perszonifikációja azonban irodalmi kérdés. A lényeg az, hogy Krisztusban le vannak győzve.

A démonokról szerző́nk így ír: „A történelem angyala az elmúlt kétszáz évben, s az elmúlt évtizedekben egyre inkább a technológia, a techné démonává változott. A démon a múlt felé hátratekintve repül előre. Elő́tte a természeti környezet, zöld füvek, maghozó gyümölcsfák, a föld vadai, a tenger halai, az ég madarai, a földön csúszómászó mindenféle állat, amelyekben élő lélek van (Gen. 1, 26-30.). A genetikai sokféleség, a bioszféra komplexitása, az élet hálózata, Gaia egysége. ${ }^{3} \mathrm{Az}$ angyal - a démon - röpte nyomán ökológiai válság."

Igen, a démonok pusztító erôk, melyek a történelemben múködnek. Azonban

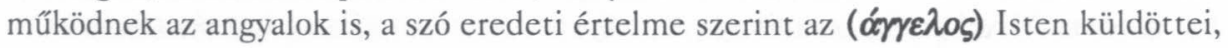
aki „angyalait szelekké teszi” (Zsid. 1,7). A Szentírás döntô üzenete, hogy az angyalok az Isten szabadítását, a Krisztusban nyerhető élet értelemmel teljes voltát hirdetik. Ott vannak a születésnél, a feltámadásnál és a mennybemenetelnél. Van egy kis könyvem a burundi vérengzésekről, melynek címe: Elhagytak bennünket az angyalok. ${ }^{4}$ Valóban rettenetes dolgok történtek ott, és napjainkban is Afrikában, Irakban és másutt. Az „angyalok” azokban visszatértek Burundiba is. Tavaly afrikai utam során megrendülve tapasztaltam, hogy a globalizáció peremén annak káros hatásait naponta érző emberek között is ott járnak az angyalok. Vigasztalnak, erősítenek, és hirdetik a Krisztusban adott szabadítást. Ez Afrika népének és az egész emberiségnek a reménysége.

Ülök a tv előtt és nézem az elém manipulált világot, és foglyává tesz. JeanFrançois Lyotard így foglalja össze témánkkal kapcsolatban a krízis lényeges vonásait:

A mai techno-tudomány beteljesiti a modern projektumát: az embert [...] a természet urává és birtokosává teszi. Ugyanakkor azonban általa az ember is mélyen destabilizálódik. Ugyanis a természet fogalmához kell számitani az emberi szubjektum minden alkotórészét - az idegrendszerét, a genetikai kódját, az agykérgi komputerét, a vizuális és auditiv érzékszerveit, a kommunikációs rendsserét, kivált a nyelvit, csoportlétének szervezödési módjait. S végül az ember tudománya, a techno-tudomány is a természet részét képezi [...]. Ilyen körülmények [...] mellett miképpen maradhat meg a leigázás eszménye? A tudósoknak a tudományról kialakitott elképzelésében ez az eszmény lassan elavul. Az ember talán csak egy különös, kiagyalt csomópont az egyetemes, az univeræum által konstituált sugáræások ingerakciójában. ${ }^{5}$

${ }^{3}$ James E. Lovelock: Gaia : a new look at life on earth. (Oxford: Oxford University Press, 1991 [1987],) uô: The ages of Gaia: a biography of our living earth; foreword by Lewis Thomas. (Oxford: Oxford University Press, 1991, [1989].)

${ }^{4}$ Hugh McCullun, The Angels have left us. The Rwanda Tragedy and the Churches (Foreword: Desmond Tutu) (Genéve: WCC Publications, Risk series) 
Ez a látás a termonukleáris vagy ökológiai katasztrófa felemlítése nélkül is eljut oda, hogy az ember felszámolja önmagát. Mondhatnánk, Vörösmarty posztmodern változatban:

„Ez az ốrült sár, Ez istenarcú lény

Nincsen remény, nincsen remény!” 6

Az én meggyőződésem szerint Krisztusban van remény. Van lehetőség arra, hogy az ember ne pusztuljon el, vagy ne jusson rabságba. Mindannyian megpörkölődünk a tûzben. A tûzoltók mind füstszagúak lesznek. Mi is része vagyunk a mai kultúrának,

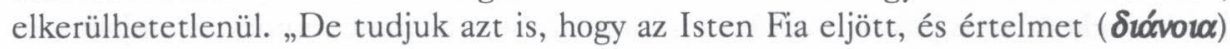
adott nekünk arra, hogy megismerjük az Igazat." (1 Ján. 5,20). Ez a Krisztusban nyert $\delta$ iónor $\boldsymbol{\alpha}$ erốt ad arra, hogy ne ragadjon el a cybervilág, és ne szakadjak ki a „termékeny televénybőll” a mesterséges világba. Ez a Krisztus ugyanis a Teremtô Isten, aki Megváltó, aki kiszabadít mindenmÉdia és ökológiamÉdia és ökológiaféle démoni erôkből, azokéból is, melyek médiahatásokban pusztítanak. Nem szükséges sem a TV, sem az Internet rabjának lenni, ha az életem Krisztusban van. Ekkor nem ők használnak engem eszközül, hanem én használom ôket eszközül Krisztus magasztalására és hirdetésére. 